\title{
KEJADIAN KEKERASAN TERHADAP ANAK TENAGA KERJA INDONESIA DI KABUPATEN KENDAL
}

\author{
Evi Widowati, \\ Universitas Negeri Semarang \\ eviwidowati@mail.unnes.ac.id \\ Widya Hary Cahyati \\ Universitas Negeri Semarang \\ widyahary27@gmail.com
}

\section{ABSTRAK}

Penelitian ini bertujuan untuk mendeskripsikan kasus Kekerasan terhadap Anak (KtA) yang orangtuanya berprofesi sebagai Tenaga Kerja Indonesia (TKI) di Kabupaten Kendal sebagai salah satu kantong TKI di Indonesia. Penelitian ini menggunakan rancangan penelitian deskriptif kualitatif dengan desain penelitian studi kasus. Teknik pengumpulan data dalam penelitian ini terdiri dari dua tahap yaitu pengumpulan data sekunder melalui BPPKB Kabupaten Kendal dan Focus Group Discussion dengan stakeholder terkait TKI di Kabupaten Kendal. Dari penelitian ini dapat diketahui bahwa faktor yang paling dominan berhubungan dengan kejadian KtA yang orang tuanya berprofesi sebagai TKI adalah faktor pendapatan dan jenis pekerjaan. Pendapatan yang cukup tinggi, yang tidak diimbangi dengan pengetahuan dan kemampuan mengelola keuangan yang baik untuk anak dan keluarganyaakan sangat berisiko. Jenis pekerjaan TKI memiliki risiko tinggi pada pola asuh anak,terutama 
karena ketidakmampuan dalam memberikan pendampingan yang memadai kepada anak-anak mereka dari pengaruh pergaulan lingkungan dan pengaruh kemajuan Teknologi Informasi.

Kata Kunci: Anak, kekerasan, Buruh Migran.

\section{ABSTRACT}

The high number of cases of Violence against Children (KtA) whose parents work as Indonesian Migrant Workers (TKI) occurred in Kendal District as one of the TKI bases in Indonesia. This research is a qualitative descriptive, using case study research design. The data collection techniques are consisted by two stages: secondary data collection through the Agency of Large Family Potential Development (BPPKB) of Kendal District and Focus Group Discussion (FGD) with relevant stakeholder. The results show that the most dominant factors related to the occurrence of violence against children are income factor and type of work. Having a high income but not balanced with good knowledge and financial management skills for children and their families is very risky. The types of work of Indonesian migrant workers have a significant impact on childcare patterns, mainly because they are unable to provide adequate assistance regarding the influence of interaction with environment and Information Technology.

Keywords: Children, Violence, Migrant Workers. 


\section{A. Pendahuluan}

Kekerasan terhadap Anak (KtA) di Indonesia setiap tahunnya selalu meningkat.Berdasarkan data, pada tahun 2015 terdapat 218 anak yang mengalami kekerasan seksual, pada tahun 2016 tercatat 120kasus, dan pada tahun 2017 tercatat 116 kasus kekerasan seksual pada anak. Untuk angka kekerasan anak secara umum, tercatat pada tahun 2016 sebanyak 3.339 kasus, sedangkan pada tahun 2017 Komisi Nasional Perlindungan Anak (Komnas PA) mencatat pengaduan kekerasan anak sebanyak 2.737 kasus. Meskipun angka kekerasan pada anak menurun pada tahun 2017 jika dibandingkan dengan angka aduan pada tahun 2016, namun jumlah kasus kekerasan anak di Indonesia masih cukup tinggi. Selama bulan April-Juli 2018, KPAI sudah menangani 33 kasus kekerasan pada anak. Angka tersebut merupakan kasus yang dilaporkan, sementara ada beberapa kasus yang karena berbagai sebab tidak terlaporkan (Komisi Perlindungan Anak Indonesia, 2018).

Akhir-akhir ini KtA baik kekerasan fisik, psikis ataupun seksual marak terjadi, baik di rumah ataupun di sekolah. Menurut hasil riset KPAI, kekerasan pada anak yang sering terjadi adalah kasus kekerasan oleh keluarga dan pengasuh, yaitu sebesar 931 kasus pada tahun 2013, sedangkan pada tahun 2014, 2015, dan 2016 berturutturut adalah 921 kasus, 822 kasus, dan 571 kasus (Komisi Perlindungan Anak Indonesia, 2018).

Penelitian United Nations Children's Fund (UNICEF) dan Pemerintah Provinsi Jawa Tengah mengenai Kekerasan terhadap Anak di Kabupaten Klaten dan Kabupaten Pemalang Jawa Tengah pada tahun 2013 menemukan masih terjadi bentuk-bentuk kekerasan fisik yang terjadi dirumah dan dilakukan olehorang yang tinggal serumah dengan 
anak. Dari 1.286 kasus yang terungkap, terlihat jumlah kekerasan fisik yang dialami oleh anak dirumah terbesar adalah dicubit $(15,9 \%)$, sedangkan kekerasan fisik yang cukup serius juga banyak terjadi pada 9 desa di Kabupaten Klaten. Seperti: dibenturkan ke dinding 13 kasus (1,01\%), dicekik 12 kasus $(0,93 \%)$, disundut dengan api rokok 9 kasus $(0,7 \%)$, dilukai dengan benda tajam 5 kasus (0,39\%) dari jumlah kasus yang terungkap, dan lainnya (Unicef, 2014).

Kenyataan di Indonesia tidak jauh berbeda dengan kondisi kekerasan anak di lingkup global. Di Indonesia, kejadian Kekerasan terhadap Anak sangat memprihatinkan. Di Indonesia pada 2012, terdapat 84 juta anak dari keseluruhan penduduk Indonesia yang berjumlah 240 juta jiwa. Dari jumlah tersebut, terdapat 44,3 juta anakyang hidup dalam kemiskinan, dimana kondisi mereka adalah hidup dengan uang kurang dari 2 dollar per hari, sedangkan anak lainnya, yaitu sekitar 30,2 juta anak hidup dengan lebih dari 2 dollar per hari. Anak yang hidup dalam kondisi kemiskinan ini merupakan salah satu faktor risiko untuk anak dapat mengalami tindak-tindak kekerasan. Berdasarkan fakta-fakta tersebut, perhatian baik dari pemerintah maupun masyarakat mutlak sangat dibutuhkan, karena anak yang hidup dalam kondisi miskin lebih rentan untuk mengalami kekerasan (Praditama et al., 2015). Kerentanan anak Indonesia dapat digambarkan dari kenyataan yang ada di masyarakat, dimana setiap tiga menit satu anak Indonesia meninggal sebelum mencapai usia 5 tahun,dan sekitar 500.000 anak per tahun meninggal akibat terkena penyakit yang sebenarnya bisa dicegah (Fataruba \& Purwatiningsih, 2009). Data dari Unicef (2014) dalam Suharto (2015) menyatakan bahwa masih terdapat sekitar 1,8 juta anak tidak diimunisasi secara lengkap, dimana hal ini merupakan tertinggi ke-3 di dunia. Terdapat 59\% anak 
Indonesia yang tidak mempunyai akta kelahiran, terdapat sekitar 2,3 juta anak berusia 7-15 tahun yang mengalami putus sekolah. Terdapat sekitar 7\% anak Indonesia yang berusia 5-17 tahun mengalami eksploitasi ekonomi, dengan melibatkan anak menjadi pekerja anak (Suharto, 2015).

Kekerasan terhadap Anak (KtA) ini dapat terjadi dikarenakan berbagai faktor antara lain: rendahnya pengetahuan orang dewasa (orang tua, guru, masyarakat, pengasuh dan lainnya) terkait batasan KtA, sistem pengasuhan yang kurang tepat dan anak-anak tinggal dalam situasi rentan, misalnya: anak tinggal dengan orang tua tunggal, anak hidup dalam panti, anak tinggal dengan keluarga anggota keluarga lain dan tidak dalam pengasuhan utuh kedua orangtuanya (Suharto, 2015).

Kabupaten Kendal adalah salah satu kantong Tenaga Kerja Indonesia (TKI) di Indonesia. Berdasarkan data Badan Nasional Penempatan dan Perlindungan TKI (BNP2TKI),Kabupaten Kendal memasok 2.400 pekerja per tahun, dan menduduki urutan kedua di Jawa Tengah pemasok TKI tertinggi setelah Cilacap (Gubernur Jawa Tengah, 2013). Berdasarkan diskusi dengan Badan Pemberdayaan Perempuan dan Keluarga Berencana (BPPKB) Kabupaten Kendal didapat hasil laporan bahwa beberapa anak menjadi korban kekerasan yang orang tua mereka berprofesi sebagai pekerja di luar negeri (TKI).

Berdasarkan latar belakang di atas, maka dilakukan penelitian tentang faktor-faktor yang berhubungan dengan kejadian Kekerasan terhadap Anak di Kabupaten Kendal, dengan studi kasus pada anak dengan orangtua yang berprofesi sebagai TKI.Penelitian ini menggunakan rancangan penelitian deskriptif kualitatif dengan desain penelitian studi kasus.Fokus dalam penelitian ini adalah mengambarkan dan menganalisis faktor-faktor yang berhubungan dengan kejadian Kekerasan terhadap 
Anak pada anak yang orangtuanya berprofesi sebagai TKI dan merumuskan bersama-sama program apa yang bisa diterapkan di Kabupaten Kendal terkait pencegahan kejadian KtA.Unit pengamatan dan unit analisis pada penelitian ini adalah faktor-faktor yang berasal dari anak, faktor-faktor yang berasal dari orangtua, faktor pelaku dan faktor lingkungan. Adapun faktor-faktor yang berasal dari anak,meliputi: usia, jenis kelamin, tingkat pendidikan dan tipe kepribadian. Faktor-faktor yang berasal dari orangtua, meliputi: tingkat pendidikan, tingkat pendapatan dan jenis pekerjaan, sedangkan faktor yang berasal dari lingkungan, terdiri dari: kondisi rumah dan tetangga/orang yang ada disekitarnya.Teknik pengumpulan data dalam penelitian ini terdiri atas dua tahap, tahap pertama adalah pengumpulan data sekunder pada instansi yang membidangi terkait perlindungan anak di Kabupaten Kendal yaitu BPРКB Kabupaten Kendal. Tahap kedua adalah penentuan peserta FGD bersama-sama antara tim peneliti dengan BPPKB untuk kemudian melakukan FGD dan wawancara dengan stakeholder terkaitdan beberapa anak untuk pengambilan data primer.

Penelitian ini diharapkan melengkapi riset terdahulu tentang anak berkaitan dengan anak dan TKI yang telah dilakukan. Suwartiningsih pada tahun 2015 yang meneliti tentang "Dampak Sosial dan Ekonomi TKW bagi Anak dan Keluarganya', serta penelitian yang dilakukan oleh Faridatul Lailiyah pada tahun 2017 tentang "Problematika Pengasuhan Anak pada Keluarga TKI". Perbedaan penelitian ini dengan penelitian sebelumnya terletak pada variabel penelitiannya, dimana pada penelitian ini lebih berfokus pada Kekerasan pada Anak yang orangtuanya berprofesi sebagai TKI di Kabupaten Kendal.

Beberapa penelitian lain terkait anak buruh migran terdapat di beberapa daerah seperti: Banyumas, 
Tulungagung, Sukabumi, dan beberapa daerah lain.Namun, pada penelitian ini lebih menekankan pada kekerasan yang terjadi pada anak yang orang tuanya berprofesi sebagai TKI. Orang tua yang berprofesi sebagai TKI akan mempengaruhi model pengasuhan terhadap anaknya, karena pengasuhan anak biasanya akan diserahkan kepada orang lain, baik itu suami, saudara atau kerabat dekat, kakek-nenek, dsb. Berbeda dengan riset yang telah ada, penelitian ini menganalisis penyebab kekerasan yang terjadi pada anak yang orang tuanya berprofesi sebagai TKI yang diharapkan dapat menjadi acuan kepada pihak terkait untuk melakukan upaya pencegahan dalam menekan jumlah kejadian kekerasan pada anak yang orang tuanya berprofesi sebagai TKI.

\section{B. Pembahasan}

\section{Kekerasan Terhadap Anak (KtA)}

Definisi buruh migran atau pekerja migran atau lebih dikenal dengan istilah Tenaga Kerja Indonesia (TKI) adalah pekerja yang bekerja di luar negeri.Dengan kata lain, buruh migran adalah orang yang bermigrasi atau pindah dari wilayah Indonesia ke luar negeri untuk keperluan bekerja. Guna keperluan bekerja itulah pekerja migran akan menetap di tempat bekerja tersebut (di luar negeri) dalam kurun waktu tertentu. Ada beberapa permasalahan yang mungkin dihadapi para TKI, diantaranya: risiko kekerasan, permasalahan kontrak, serta permasalahan yang menyangkut keluarga yang ditinggalkan di tanah air.

Menurut UU No. 35 tahun 2014 tentang Perlindungan Anak, yang dimaksud kekerasan adalah setiap perbuatan terhadap Anak yang berakibat timbulnya kesengsaraan atau penderitaan secara fisik, psikis, seksual, dan/atau penelantaran, termasuk ancaman untuk melakukan 
perbuatan, pemaksaan, atau perampasan kemerdekaan secara melawan hukum (UU 35 tahun 2014). Ada beberapa penyebab terjadinya Kekerasan terhadap Anak, diantaranya karena anak sebagai korban yang cenderung lebih bersikap menutup diri, takut, dan bersikap pasrah daripada mencoba melawan, kecuali pada anak yang lebih besar. Ada juga anggapan bahwa Kekerasan terhadap Anak merupakan suatu yang bersifat kebiasaan dari masyarakat danmenganggap bahwa persoalan kekerasan ini adalah sebagai masalah internal keluarga.Sehingga kurang layak atau "tabu" untuk diekspose keluar secara terbuka, karena hal ini merupakan aib keluarga, kecuali jika anaknya telah menjadi korban yang cukup serius dari tindak kekerasan fisik, psikis atau seksual. Adanya paradigma di masyarakat bahwa orangtua "berhak" memperlakukan anaknya dengan cara apapun atas nama pendidikan, budaya, budi pekerti, dendam masa lalu, harapan/obsesi, atau menjadikan anak agar bisa menjadi lebih baik dan penurut. Selain itu, kurangnya pemahaman agama dan keterbatasan pendidikan juga dapat menjadi salah satu penyebab Kekerasan terhadap Anak.

Kekerasan terhadap Anak juga bisa didefinisikan sebagai segala bentuk tindakan kekerasan yang dilakukan terhadap anak sebagai korban, baik itu dilakukan secara fisik, seksual, emosional, ataupun tindakan pengabaikan terhadap anak sehingga dapat membahayakan kondisi anak tersebut.Faktor-faktor yang bisa menjadi penyebab terjadinya Kekerasan terhadap Anak diantaranya karena anak berpotensi sebagai korban, orang dewasa berpotensi sebagai pelaku kekerasan, peluang kekerasan tanpa pengawasan dan perlindungan, serta adanya pencetus dari korban atau pelaku. Upaya pencegahan Kekerasan terhadap Anakini membutuhkanadanya komitmen dari pemerintah 
yang bersinergi dengan masyarakat (Mackowlez, 2013; Noh \& Talaat, 2012; Gubernur Jawa Tengah, 2013).

Kekerasan adalah tindakan yang dilakukan secara sengaja, yang dapat mengakibatkan cidera atau luka fisik dan/atau tekanan mental. Menurut Campbell dan Humpherey, kekerasan anak adalah semua tindakan yang dapat mencelakai kesehatan dan kesejahteraan anak yang dilakukan oleh seseorang, dimana orang tersebut harusnya bertanggung jawab terhadap kesehatan dan kesejahteraan anak tersebut. Kekerasan anak bisa dibagi menjadi 4 jenis, yaitu:emotional abuse, verbal abuse, physical abuse, dan sexual abuse. Verbal abuse adalah kekerasan dengan verbal, misalnya orang tua yang membentak anak ketika anak ingin mendapatkan perhatian dari orang tua. Orang tua biasanya akan menyuruh anak untuk "diam" atau "jangan rewel", atau bila anak kurang bisa melakukan sesuatu, orang tua akan menggunakan kekerasan verbal berupa mengatai anak dengan sebutan-sebutan buruk, seperti: "dasar bodoh" atau "cerewet", "kamu kurang ajar", dan seterusnya (Putri, dkk, 2012).

Himpitan ekonomi merupakan salah satu penyebab terjadinya Kekerasan terhadap Anak.Adanya anggapan bahwa Kekerasan terhadap Anakhanya bersifat kasuistis, yang terjadi hanya pada keluarga tertentu yang dianggap bermasalah, baik secara genetik maupun faktor lingkungan.Pelaku kekerasan ini biasanya memiliki masa lalu yang buruk, sehingga menjadi "role model" pola asuh (parenting skill).Kekerasan terhadap Anakjuga sering kali terjadi karena hubungan pasangan suami istri yang tidak harmonis, sehingga anak sering kali menjadi sasaran kemarahan, untuk melampiaskan dendam atau amarah. Kasus yang sering kali terjadi karena pengaruh lingkungan atau peer group, serta paparan media, termasuk tayangan 
media yang tidak sehat, vulgar, satanic, pornografi, serta syarat dengan kekerasan dan konsumerisme.

\section{Model Pengasuhan dan Faktor Penyebab Kekerasan Terhadap Anak TKI di Kabupaten Kendal}

Berdasarkan hasil wawancara dengan Ketua Serikat Buruh Migran Indonesia (SBMI) Provinsi Jawa Tengah, menyatakan bahwa model pengasuhan anak buruh migran atau TKI di Kabupaten Kendal ada beberapa cara, yaitu diasuh oleh suami atau pasangan yang sah, atau bisa juga dititipkan pada kerabat dekatnya, misalnya: nenek, kakek, paman/bibi, atau kerabat lainnya. Bagi anak yang diasuh hanya oleh ayahnya, sebagian merasa kurang kasih sayang dan bahkan sering terjadi kasus penelantaran anak. Akhirnya anak akan mencari teman di luar rumah, dengan tanpa pengawasan yang memadai sehingga hal ini menjadi sangat berisiko untuk anak mempunyai lingkungan pergaulan yang buruk.

Model pengasuhan yang kedua adalah yang dititipkan kepada kerabat dekat.Model ini juga mempunyai kelemahan, dimana kerabat yang dititipi anak untuk diasuh sering mengalami dilema.Perlakuan yang tegas dalam pengasuhan sering dianggap sebagai suatu Kekerasan terhadap Anak, tetapi apabila diperlakukan kurang tegas maka sering dianggap sebagai pembiaran atau penelantaran anak. Terbatasnya tingkat pendidikan dan pengetahuan tentang pengasuhan anak akanmempengaruhi perilaku para pengasuh anak yangakan berdampak pada manifestasi perilaku dari anak tersebut. Model pengasuhan ini menjadi salah satu faktor pendorong muncul fenomena yaitu anakanak yang berusia di atas 13 tahun menjadi anak-anak "pank" dan banyaknya anak putus sekolah.

Kantong TKI di Kabupaten Kendal sebagian besar ada di Kecamatan Pegandon, Ringin Arum, dan Ngampel. 
Dari 30 anak yang orangtuanya berprofesi sebagai TKI yang dipilih secara acak, maka dapat diketahui 70\% diantaranya kehidupan dan pengasuhan mereka dititipkan kepada nenek/kakeknya atau kerabat dekat lainnya, dan 30\% diasuh oleh salah satu orang tuanya yang tidak bekerja di luar negeri. Berdasarkan Focus Group Discussion (FGD) dan wawancara dengan para Satuan Kerja Perangkat daerah (SKPD) di Kabupaten Kendal, diketahui bahwa ketika terjadi tindak kekerasan di keluarga sebagian besar proses pelaporan yang ada hanya sampai di tingkat kelurahan walaupun ada sebagian kecil yang melaporkan hingga di Lembaga Konsultasi Kesejahteraan Keluarga (LK3). Proses pelaporan biasanya dilakukan oleh perangkat desa kemudian perangkat akan melakukan proses pendekatan dengan pelaku untuk tidak melakukan hal serupa dikemudian hari.

Menurut hasil wawancara dengan anak-anak yang menjadi pelaku tindak kriminal atau anak yang dianggap masyarakat sebagai "anak nakal" disebabkan karena mereka kurang perhatian, kasih sayang dan bimbingan dari orang tua mereka. Menurut keterangan dari pihak kepolisian pada saat FGD, kasus kekerasan yang pelakunya anak yang orang tuanya berprofesi sebagai TKI mencapai kurang lebih 5 kasus per tahunnya dimana kasusnya masuk hingga proses di kepolisian.

Faktor yang mempengaruhi tingginya angka Kekerasan terhadap Anak (KtA) di Kabupaten Kendal dipengaruhi oleh empat hal yaitu faktor anak, orang tua, pelaku kekerasan dan lingkungan.

a. Faktor Anak

Faktor anak yang berpengaruh terhadap kejadianKekerasan terhadap Anak meliputi:usia anak, jenis kelamin, tingkat pendidikan, tipe kepribadian dan kondisi 
anak. Dari hasil penelitian diketahui bahwa tidak terdapat batasan usia yang spesifik terkait anak yang menjadi korban kekerasan, karena banyak ditemukan anak yang mengalami kekerasan berusia menyebar pada anak diusia SD, SMP ataupun SMA. Namun menurut informan kunci menyebutkan bahwa anak yang masih kecil lebih rentan mendapatkan kekerasan dari pengasuhnya yaitu anak di usia TK dan SD.

Dari proses wawancara dan FGD menyatakan bahwa jenis kelamin tidak berpengaruh pada kejadian Kekerasan terhadap Anak (KtA) karena anak laki-laki ataupun perempuan keduanya sama-sama rentan menjadi korban ataupun pelaku kekerasan. Sedangkan untuk kekerasan seksual yang menjadi korban mayoritas adalah anak perempuan.

Beberapa kasus yang terlaporkan mayoritas terjadi pada anak-anak di usia SD dan SMP.Khusus untuk anak sebagai pelaku, faktor drop out dari sekolah juga sangat berkontribusi terhadap kejadian KtA. Masalah drop out ini cukup banyak terjadi pada anak-anak yang orang tuanya berprofesi sebagai TKI karena pudarnya keinginan mereka untuk melanjutkan sekolah yang disebabkan karena lemahnya pendampingan dan motivasi dari orang tua sehingga anak tidak mempunyai kemampuan dalam menyikapi dampak negatif dari sistem relasi pergaulan yang ada.

Faktor kepribadian anak dalam studi ini kurang bisa terungkap dengan jelas saat proses pengambilan data melalui FGD yang dilakukan karena informan yang menjadi peserta FGD selama ini tidak pernah melakukan pengamatan mendalam terkait aspek kerentanan kepribadian pada anak yang menjadi korban ataupun pelaku pada tindak kekerasan. 
Anak-anak yang orangtuanya berprofesi sebagai TKI sering merasakan kurang kasih sayang, sehingga mereka menjadi sangat rentan untuk melakukan hal-hal yang cenderung berlebihan yaitu diluar norma yang ada di masyarakat, sehingga masyarakat sering memberikan stigma buruk dengan menyebutnya "anak nakal”.

\section{b. Faktor Orang tua}

Faktor orang tua yang berpengaruh terhadap kejadian Kekerasan terhadap Anak terdiri dari: tingkat pendidikan, tingkat pendapatan dan jenis pekerjaan. Berdasarkan hasil penelitian terhadap 30 anak yang dipilih secara acak, yang orang tuanya berprofesi sebagai TKI, dapat diketahui bahwa sebagian besar tingkat pendidikan orang tua mereka yang berprofesi sebagai TKI adalah SD (40\%), SMP (40\%), dan SMA (20\%).

Orangtua yang berprofesi sebagai TKI rata-rata memiliki pendapatan yang cukup tinggi. Beberapa orang tua yang berprofesi sebagai TKI beranggapan bahwa anak mereka akan bahagia apabila mereka mampu mencukupi kebutuhan finansial anak walaupun dengan tanpa mencukupi kebutuhan kasih sayang yang cukup pada mereka. Rata-rata mereka mengirimkan uang jajan kepada anak-anak mereka hingga mencapai satu juta rupiah perbulan untuk anak usia sekolah SMP sehingga terkadang membuat anak hidup dengan gaya hidup yang berlebihan, salah memilih teman, salah pergaulan, dan tidak jarang anak berbuat yang melewati batas, misalnya menkonsumsi minuman keras, narkoba, dan kebut-kebutan.Disisi lain orangtua yang tidak berprofesi sebagai TKI rata-rata hanya memberikan uang jajan kepada anak mereka yang berada di usia SMP dalam 1 bulan hanya mencapai kurang lebih 125 hingga 150 ribu rupiah per bulan. Sehingga dapat dikatakan bahwa anak-anak yang orangtuanya TKI 
memperoleh uang jajan 7 hingga 8 kali lebih besar dari anak yang orangtuanya bukan TKI di Kabupaten Kendal.

Disisi lain pada beberapa kasus yang terungkap dari informan bahwa uang kiriman dari istri yang berprofesi sebagai TKI yang dikirimkan kepada suaminya jarang digunakan secara optimal untuk kepentingan terbaik bagi anak. Meskipun ada yang diperuntukkan untuk anak namun jumlahnya tidak signifikan. Berdasarkan hasil FGD dengan perangkat desa di Kabupaten Kendal, beberapa diantara informan menyatakan bahwa beberapa suami banyak menggunakan uang kiriman istrinya untuk hidup berfoya-foya bahkan untuk belanja seks, ditunjang wilayah Kabupaten Kendal ini banyak dikelilingi areaarea prostitusi, sehingga penelantaran ekonomi juga kerap terjadi pada anak.

Terkadang kondisi keluarga ini memburuk saat sang istri pulang dari luar negeri dan melihat kenyataan bahwa suami tidak bisa mempertanggungjawabkan penggunaan uang hasil kerja yang dikirimkan sang istri selama mereka bekerja, bahkan tidak jarang kondisi ini berakhir dengan perceraian. Kondisi pola asuh yang tidak kuat dan ditambah dengan perceraian yang terjadi pada orang tua tentunya akan memberikan dampak negatif yang jauh lebih besar terhadap tumbuh kembang anak.

Profesi TKI menuntut orang tua baik ayah ataupun ibu harus bekerja diluar rumah dalam waktu yang relatif lama, dimana biasanya mereka bekerja dengan jarak yang relatif jauh sehingga sering berdampak pada lamanya waktu mereka harus meninggalkan anak-anak mereka dirumah tanpa pengasuhan langsung dari kedua orang tua. Jenis pekerjaan terbesar dari TKI yang berasal dari Kabupaten Kendal ini adalah sebagai pembantu rumah tangga.

Rata-rata yang berprofesi sebagai TKI adalah perempuan (ibu), dan dari informan menyatakan bahwa 
kemungkinan anak menjadi "nakal" atau lebih berpotensi menjadi pelaku kekerasan apabila mereka kurang mendapatkan perhatian khusus dari ibu mereka ketimbang dari ayah mereka. Sementara di sisi lain, tuntutan kebutuhan hidup memaksa para ibu harus bekerja di luar rumah hingga waktu yang relatif lama sehingga mereka lebih memilih menitipkan anak-anak mereka kepada suami mereka, nenek, kakek atau kerabat keluarga lainnya. Disampaikan juga oleh informan bahwa di Kabupaten Kendal sebagian besar nenek merasa lebih sayang terhadap cucu mereka daripada terhadap anak mereka sendiri, sehingga mereka cenderung “memanjakan" anakanak yang ada dalam pengasuhannya. Disisi lain banyak suamiyang tidak mengasuh dan memperhatikan anak-anak mereka dengan baik. Bahkan pemicu Kekerasan terhadap Anakbanyak dipicu oleh faktor perselingkuhan yang terjadi pada orang tua si anak karena ayahnya atau ibunya tidak bersama dalam waktu yang relatif lama. Sehingga beberapa kasus terungkap ayah atau ibu mereka memiliki "wanita atau pemuda idaman lain" baik dalam hubungan perselingkuhan atau pernikahansiri. Tentunya hal inimenyebabkan ketidakharmonisan dalam rumah tangga yang akan berdampak pada pola asuh yang diberikan kepada anak-anak mereka. Anak menjadi lebih rentan mendapat kekerasan baik verbal, psikis ataupun fisik dari orang tua mereka sendiri dan sering dijadikan sebagai objek pelampiasan rasa marah dari orang tua mereka khususnya ketika orangtua mereka sedang mengalami masalah dalam kehidupan sehari-hari.

Kabupaten Kendal terdapat anak yang jarang diasuh secara langsung dan secara penuh oleh ayahnya sendiri apabila ibu mereka bekerja menjadi TKI, mereka lebih sering dititipkan kepada nenek atau kakeknya. Sementara sebagian besar suami yang ditinggal istrinya bekerja sebagai 
TKI mereka bekerja sebagai petani atau buruh.Dimana mereka sangat mengandalkan kiriman uang penghasilan dari istrinya.

\section{c. Faktor Pelaku}

Gambaran pelaku Kekerasan terhadap Anak yang orang tuanya berprofesi sebagai TKI antara lain adalah: orang tua mereka sendiri (ayah atau ibu), nenek, kakek, teman, tetangga, dan guru di sekolahnya. Bahkan dari studi kasus diketahui bahwa ada didaerah Patean guru SD terungkap telah mengancam 9 anak dan melakukan pencabulan berupa meraba-raba tubuh si anak. Sementara banyak juga anak-anak yang diasuh oleh nenek dan kakek mendapatkan kekerasan secara langsung oleh nenek atau kakek mereka lantaran tidak mampu menyikapi dan menghadapi kenakalan yang muncul pada diri si anak.

Padaanak yang sebagai pelaku tindakkekerasan seksual banyak disebabkan karena pelaku pernah melihat film porno sebelumnya sehingga memicu pelaku anak tersebut memiliki dorongan seksual yang tinggi atau ingin mencoba-coba melakukan sebagaimana yang ada dalam adegan di film porno tersebut. Untuk kekerasan fisik yang pelakunya anak juga banyak dipengaruhi oleh tontonan TV, film kartun atau game on line yang didalamnya banyak menyajikan kekerasan yang dapat berpengaruh negatif pada perilaku anak karena dapat mendorong anak untuk meniru adegan yang mereka tonton.

\section{d. Faktor Lingkungan}

Faktor lingkungan yang berpengaruh terhadap kemungkinan terjadinya Kekerasan terhadap Anak adalah kondisi rumah dan tetangga/orang yang ada disekitarnya. Tidak terdapat perbedaan yang menonjol terkait hubungan kondisi rumah dengan kerentanan kejadian Kekerasan 
terhadap Anak, baik yang orang tuanya berprofesi sebagai TKI ataupun tidak. Namun untuk kekerasan seksual terlihat anak menjadi lebih berisiko apabila tinggal sendirian hanya dengan ayah mereka dirumah. Karena kondisi rumah yang sepi dan kondisi rumah yang kecil serta sempit membuat ayah dan anak tidur pada tempat yang sama, hal ini memberi peluang si ayah untuk melakukan tindakan kekerasan seksual pada anak mereka sendiri.

Pada Kabupaten Kendal terungkap bahwa sebagian besar orang masih mempunyai anggapan apabila terjadi tindak kekerasan dirumah maka hal tersebut masih dianggap sebagai urusan internal dalam rumah tangga mereka masing-masing, sehingga terkadang membuat mereka merasa sungkan jika harus menegur ketika melihat Kekerasan terhadap Anakyang terjadi dilingkungan sekitar mereka.

\section{Kejadian Kekerasan terhadap Anak (KtA) dan Dampaknya}

Bentuk Kekerasan terhadap Anak yang banyak terjadi di Kabupaten Kendal antara lain berupa: kekerasan fisik, kekerasan psikis, verbal, kekerasan seksual dan penelantaran. Adapun dari jenis kekerasan fisik yang terjadi antara lain yaitu: dijewer, dicubit, dan dipukul dengan alat (misalnya dengan sapu). Contoh kasus berat yang terakhir ditangani oleh kepolisian adalah kasus pembunuhan yang pelakunya adalah anak yang membunuh temannya sendiri di mana pelakunya adalah anak yang orangtua berprofesi sebagai TKI. Pelaku menusuk korban lantaran ingin menguasi motor si korban. Kasus pembunuhan anak dengan pelaku anak ini akhirnya diputus dengan 10 tahun penjara melalui sistem peradilan pidana anak.

Pengasuh alternatif yaitu nenek atau kakek menurut informan juga sering mengeluarkan kata-kata kasar dan 
membentak anak karena mereka merasa kuwalahan dalam mengasuhdan menghadapi anak-anak tersebut. Informan mengungkap dari kekerasan psikis atau verbal yang anak dapatkan dari pengasuhnya membuat anak menjadi semakin "nakal atau resisten". Selain dari nenek atau kakek pelaku kekerasan psikis atau verbal banyak juga dilakukan ibu kandung anak ketika mereka tinggal bersama.

Kasus pemerkosaan juga pernah terungkap beberapa tahun terakhir yang pelakunya adalah anak dengan orang tua berprofesi sebagai TKI. Dari data kepolisian terungkap bahwa selama tahun 2017sudah masuk 14 kasus kekerasan seksual, antara lain: berupa kekerasan di bawah ancaman dengan jenis pencabulan (diraba-raba), persetubuhan dan pemerkosaan. Korban langsung dirujuk ke Rumah Sakit setempat untuk memperoleh pemeriksaan hingga rehabilitasi yang adekuat. Penuturan ini diperkuat oleh pernyataan informan dari Pengadilan Negeri Kabupaten Kendal bahwa laporan kasus kekerasan seksual relatif meningkat setiap tahunnya.

Kasus inses yang dilakukan ayah kepada anak perempuan juga terjadi di Kabupaten Kendal. Inses yang terjadi ini disebabkan karena dorongan biologis atau kebutuhan seksual pelaku yang tinggi, adanya kelainan, atau pengaruh dari faktor lingkunganyang mendukung, seperti kondisi dan situasi rumah tinggal. Dilaporkan terdapat 3 kasus dalam waktu tahun 2014-2015. Hal itu terjadi dipicu karena ibunya berprofesi sebagai TKI yang meninggalkan rumah dalam waktu relatif lama,sedangkan ayah hanya tinggal di rumah dengan anak perempuannya.

Kasus penelantaran sering juga ditemui di Kabupaten Kendal khususnya pada anak-anak yang orangtuanya berprofesi sebagai TKI. Misalnya: anak tidak terurus mulai dari pengasuhannya bahkan kebutuhan pokok seperti: makan, minum dan pakaiannya sehari-hari. 
Kejadian Kekerasan Terhadap Anak (KtA) ini secara umum berdampak terhadap anak baik dampak fisik maupun psikologis. Anak korban kekerasan terlihat menjadi semakin "nakal atau resisten", anak menjadi pendiam, pemurung, tertutup, kurang percaya diri (minder), bahkan mendorong mereka melakukan suatu perbuatan yang melanggar hukum, misalnya: karena penelantaran (mereka lapar sehingga membuat mereka mencuri makanan) dan lain sebagainya.

Jenis KtA yang berdampak sangat berat bagi anak adalah kekerasan seksual. Anak korban kekerasan seksual terlihat pendiam, tertutup, kurang percaya diri (minder) juga mengakibatkan banyaknya dispensasi nikah untuk anak dari Pengadilan Agama. Menurut penuturan informan dari Pengadilan Agama di Kabupaten Kendal memiliki cukup banyak kasus dispensasi nikah walaupun jumlahnya masih kurang dari 10 per tahun. Dispensasi nikah diberikan karena adanya kehamilan atau keinginan kuat dari orang tua untuk menjodohkan anaknya.

Dari faktor-faktor diatas dapat diketahui bahwa faktor yang paling dominan berhubungan dengan kejadian kekerasan pada anak dengan orang tua berprofesi TKI yaitu: faktor pendapatan dan jenis pekerjaan.Pada faktor pendapatan, orangtua yang berprofesi sebagai TKI rata-rata memiliki pendapatan yang cukup tinggi. Hal ini banyak mendorong para orang tersebut memberikan uang jajan kepada anaknya secara berlebihan dengan tanpa adanya bimbingan atau kapasitas untuk mampu mengelola uang mereka secara bijak dan benar kepada anak-anak mereka, sehingga yang terjadi uang tersebut dimanfaatkan oleh anak untuk berbuat hal-hal yang melewati batas, misalnya mengkonsumsi minuman keras, narkoba, kebut-kebutan, dll. 
Pada sisi lain, beberapa kasus yang terungkap dari informan bahwa uang kiriman dari istri yang berprofesi sebagai TKI yang dikirimkan kepada suaminya jarang digunakan secara optimal untuk kepentingan terbaik bagi anak, bahkan beberapa suami banyak menggunakan uang kiriman istrinya untuk hidup berfoya-foya bahkan untuk belanja sex, sehingga penelantaran ekonomi juga kerap terjadi pada anak. Kondisi ini sangat berpotensi untuk menimbulkan konflik rumah tangga saat sang istri pulang bekerja dari luar negeri, sehingga banyak hubungan yang berakhir dengan perceraian. Dari konflik rumah tangga dan perceraian ini membuat anak dalam situasi pengasuhan yang semakin tidak kondusif, bahkan anakpun juga sangat berpotensi untuk mendapat kekerasan dari orang tua mereka sendiri. Dari jumlah kurang lebih 3.000 kasus per tahun yang masuk ke Pengadilan Agama dapat diketahui bahwa mayoritas adalah kasus perceraian.

Pada faktor jenis pekerjaan profesi TKI menuntut orang tua harus bekerja di luar rumah baik ayah ataupun ibu. Dimana mereka bekerja dengan jarak yang relatif jauh sehingga sering berdampak pada lamanya waktu mereka harus meninggalkan anak-anak mereka dirumah tanpa perawatan dan pengasuhan adekuat langsung dari orang tua si anak. Sehingga anak tidak atau kurang mendapatkan perhatian khususnya dari ibu mereka. Sementara disisi lain ada pengaruh pergaulan, rendahnya bimbingan dan pendampingan anak saat berinteraksi dengan Teknologi Informasi (TI) misalnya internet dan media sosial, serta pola asuh anak yang diberikan oleh orang tua pengganti yang kurang memadahi membuat anak menjadi rentan baik menjadi korban atau pelaku kekerasan. 


\section{Upaya Pencegahan Kekerasan Terhadap Anak}

Cara orang tua dalam mendidik dan membesarkan anak dalam sebuah keluarga sangat penting, karena akan berpengaruh terhadap psikologis anak. Namun kenyataan di masyarakat, lingkungan yang kondusif terhadap perkembangan anak jarang terjadi, justru kekerasan verbal terhadap anak yang lebih sering terjadi. Contoh yang paling sering kita temukan adalah panggilan seperti "si hitam", "si ndut", "anak malas", hal ini bisa menimbulkan efek negatif terhadap psikologis anak. Proses labeling terhadap anak berdasarkan karakter fisik, pribadi, maupun kebiasaan yang mungkin bisa berimbas pada psikologis anak, meskipun mungkin panggilan tersebut merupakan "panggilan kesayangan" dari orang atau orang-orang yang dekat dengan anak, dengan tujuan supaya anak lebih rajin (Armalis, 2008; Fiqi, 2014).

Berdasarkan penelitian, usia 3 tahun merupakan usia dimana merupakan masa-masa pembentukan otak dan perilaku anak. Pada masa ini, anak dianggap sangat kritis dikarenakan masa ini merupakan masa perkembangan emosi dan psikologis.Perkembangan superego juga terjadi pada masa ini, dimana kesadaran anak mulai muncul. Kenakalan anak pada usia 3 sampai 6 tahun merupakan hal yang wajar, karena pada masa ini anak sedang mempelajari lingkungan, sehingga terlihat kreatif. Namun,orangtua terkadang melihat hal tersebut sebagai kenakalan dan dianggap sangat mengganggu, sehingga orang tua tidak segan-segan untuk melakukan kekerasan verbal.Bentuk kekerasan verbal yang sering dilakukan adalah membentak dan mengabaikan anak (Ikawati, 2013; Suharsono, 2009).

Kekerasan verbal adalah kekerasan terhadap perasaan, dimana pelaku menggunakan kata-kata yang kasar terhadap korban dan tanpa menyentuh fisiknya. 
Kata-kata yang bersifat memfitnah atau kata-kata yang bersifat mengancam, menakutkan, menghina, atau katakata yang bersifat membesar-besarkan kesalahan orang lain merupakan contoh kekerasan verbal. Kekerasan verbal bisa dirasakan oleh korban sebagai salah satu bentuk teror.Orang tua bisa meneror anak ketika orang tua menyerang anak dengan cara membentak atau melampiaskan kemarahannya kepada anak. Hal tersebut dapat menciptakan keadaan yang menakutkan bagi anak.Faktor yang menyebabkan orang tua melakukan tindakan kekerasan verbal terhadap anak, salah satunya adalah karena faktor anak.Pada anak yang berusia 3 sampai 4 tahun mempunyai kemampuan dalam memperhatikan stimulus yang cukup tinggi. Anak pada usiatersebut lebih memperhatikan sesuatu yang dianggapkan cukup mencolok, dan kemudian mereka akan menirunya (Munawati, 2011; Flaherty et al., 2008).

Faktor lain yangjuga berpengaruh terhadap terjadinya kekerasan verbal terhadap anak adalah adanya faktor dari dalam diri orang tua tersebut. Orang tua yang memiliki karakter keras, akandengan mudah berkata keras atau kasar terhadap anaknya, dan ini merupakan salah bentuk kekerasan verbal pada anak. Karakter orang tua yang seperti itu adalah bentukan dari orang tua sebelumnya. Cara mendidik dan membimbing anak akansangat berpengaruh terhadap pembentukan karakter. Kekerasan verbal yang dilakukan oleh orang tua terhadap anak juga karena karakter yang dimiliki oleh orang tua mereka sebelumnya. Semua tindakan kepada anak, akan direkam dalam alam bawah sadar anak, dan ini akan dibawa oleh anak hingga mereka dewasa nanti (Hyoscyamina, 2011; Aulina, 2013).

Anak yang mendapatkan perilaku kejam dari orang tuanya akan tumbuh menjadi agresif, sehingga nantinya ketika mereka menjadi orang tua, mereka akan memiliki karakter yang hampir sama dengan orang tua mereka yang 
terdahulu. Dalam melakukan kekerasan verbal, sebagian orang tua mempunyai tujuan untuk kebaikan anak.Pada anak yang berusia antara 3 sampai 4 tahun merupakan masa dimana mereka mengembangkan inisiatif untuk selalu ingin mencoba hal-hal baru.Dampak jangka panjang dari kekerasan verbal yang dilakukan oleh orang tua terhadap anak salah satunya adalah dapat menimbulkan rantai kekerasan yang berkesinambungan pada keluarga. Anak yang pernah mendapatkan kekerasan verbal dari orang-orang terdekatnya akan berisiko untuk dapat melakukan hal yang sama di kelak kemudian hari terhadap anak-anaknya pada saat mereka menjadi orang tua. Hal ini sesuai dengan istilah yang sering terdengar di masyarakat, bahwa anak-anak merupakan peniru ulung (Mackowlez, 2013; Ahmed et al., 2015).

Banyak orang tua yang beranggapan bahwa melarang anak dengan cara memukul merupakan cara yang paling ampuh dalam membuat anak patuh. Menurut para orang tua, pukulan akan memberikan suatu perasaan yang tidak enak pada anak, tapi mempunyai efek yang menakutkan bagi anak. Secara teori, hukuman-hukuman fisik tersebut, seberapapun ringannya, akan memberikan dampak yang tidak baik bagi perkembangan anak-anak. Di Indonesia, anak-anak usia 6-12 tahun paling sering mengalami kekerasan seksual. Berdasarkan data, sebanyak 33\% dari anak-anak tersebut mengalami kekerasan seksual, dan 28,8\% mengalami kekerasan emosional, sedangkan yang mengalami kekerasan yang bersifat fisik sebanyak 24,1\% (Komisi Perlindungan Anak Indonesia, 2018, Syarniah \& Lestari, 2014).

Adapun tempat terjadinya kekerasan, sebagian besar terjadi di rumah, sebanyak 129 kasus, kekerasan yang terjadi di jalanan sebanyak 79 kasus, kekerasan yang terjadi di sekolah sebanyak 10 kasus, kekerasan yang terjadi di 
lembaga keagamaan sebanyak 2 kasus, kekerasan yang terjadi di sektor perekonomian sebanyak 21 kasus. Khusus untuk kekerasan seksual, tempat yang paling banyak terjadi adalah di rumah, yaitu sebanyak 48,7\%, kekerasan seksual yang terjadi di tempat umum sebanyak 6,1\%, kekerasan seksual yang terjadi di sekolah sebanyak 4,1\%, kekerasan seksual yang terjadi di tempat kerja sebanyak 3,0\%, dan di tempat lainnya sebanyak 0,4\% (Komisi Perlindungan Anak Indonesia, 2018).

Pada anak usia sekolah, mereka masih dalam tahap mencari jati diri, sehingga mereka seringkali masih labil dalam bersikap. Hal tersebut merupakan salah satu penyebab para anak usia sekolah masih sering melakukan kesalahan. Kesalahan-kesalahan yang dilakukan oleh anakanak tersebut seringkali dapat memicu kemarahan dari orang tua, dan menyebabkan para orang tua menghukum anak tanpa mempertimbangkan dampak dari hukuman yang diberikan kepada anak tersebut. Sebaiknya orang tua perlu menyadari bahwa kekerasan yang dilakukan oleh orang tua akan berdampak buruk terhadap perkembangan anak di kemudian hari. Masih banyak carayang bisa dilakukan orang tua untuk penyelesaian dan menangani kesalahan yang diperbuat anak, sehingga anak tidak melakukan kesalahan yang sama (Hartanto, 2009; Nindya \& Margaretha, 2012).

Peranan orang tua dalam pembentukan karakter anak sangat penting, sehingga sikap orang tua terhadap anak juga ikut menentukan karakter anak.Hal inilah yang menyebabkan anak memiliki karakter yang berbeda. Karakter anak juga sangat dipengaruhi oleh lingkungan keluarga.Banyak faktor yang dapat memicu terjadinya Kekerasan terhadapAnak.Beberapa orang tua mempunyai alasan untuk menghukum anak dalam menyelesaikan masalah anak, salah satunya dengan kekerasan. 
Faktor kenakalan anak dan keadaan internal keluarga merupakan faktor terbesar penyebab terjadinya Kekerasan terhadapAnak (Hidayat \& Ery, 2014; Cheng et al., 2011).

Perlindungan setiap warga dari kekerasan merupakan implementasi dari pemenuhan Hak Asasi Manusia (HAM). Kekerasan tidak boleh dilakukan dalam bentuk apapun dan kepada siapapun. Mengingat Anak adalah Masa depan Bangsa maka kekerasan terutama terhadap anak harus ditanggulangi. Dengan banyaknya Kekerasan terhadap Anak di Indonesia, maka dapat dikatakan bahwa sebagian besar anak di Indonesia hidup dalam bayang-bayang kekerasan, dan hal tersebut dapat menyebabkan trauma seumur hidupnya. Sebagai generasi penerus bangsa, kualitas kehidupan anak saat ini merupakan gambaran dari kualitas kehidupan Bangsa Indonesia di masa yang akan datang. Bila terjadi pembiaran Kekerasan terhadap Anak, itu artinya sama dengan menciptakan masa depan bangsa yang suram di masa mendatang. Kekerasan yang dilakukan terhadap anak di Indonesia merupakan fakta penting, karena hal tersebut akan berakibat fatal. Kekerasan terhadap Anak bertentangan dengan norma agama, norma hukum, dan norma sosial(Ikawati, 2013; Peni, 2013).

Pemberitaan tentang fenomena Kekerasan terhadap Anak yang terjadi di masyarakat, melalui media massa, baik media elektronik maupun media cetak semakin masif. Kekerasan yang banyak terjadi terhadap anak baik berupa kekerasan secara fisik maupun kekerasan secara nonfisik.Namun karena kesadaran masyarakat yang kurang, maka terkadang kekerasan yang terjadi terhadap anak itu dianggap sebagai hal yang wajar. Hal ini disebabkan karena hal tersebut terjadi secara berulang-ulang, sehingga hal tersebut dianggap menjadi suatu kewajaran dan bisa saja dianggap benar (Hartanto, 2009; Breen et al., 2015).

Pencegahan KtA perlu bersifat sinergis dan stategis. 
Pemilihan tayangan bagi anak diperlukan mengingat misalnya pada tayangan televisi, masyarakat sering diperlihatkan acara-acara yang menampilkan adegan kekerasan secara eksplisit, atau ejekan-ejekan yang menyangkut kekurangan dalam bentuk fisik seseorang, dan hal itu sering menjadi bahan ejekan, candaan, bahkan cemoohan. Ironisnya, justru para masyarakat yang menjadi penonton akan merasa terhibur. Hal ini terbukti dengan menjamurnya acara-acara televisi yang menampilkan adegan kekerasan atau semacamnya, dan acara-acara semacam talk show yang isinya penuh ejekan antar host atau semacamnya justru menjadi program favorit, yang ditunjukkan dengan rating yang sangat tinggi, dan waktu tayang berada pada jam-jam khusus (prime time). Dengan kata lain, media massa seperti televisi berkontribusi dalam terjadinya Kekerasan terhadap Anak.

Hal ini tidak boleh dilakukan pembiaran agar perilaku-perilaku yang mengandung unsur kekerasan tidak menjadi kebiasaan yang sering dilakukan dalam kehidupan masyarakat. Demikian juga dengan perilaku Kekerasan terhadap Anak, yang bisa saja dianggap sebagai sesuatu yang wajar terjadi, meskipun hal Kekerasan terhadap Anak ini merupakan hal yang melanggar hak-hak kemanusiaan seseorang. Pencegahan Kekerasan terhadap Anak maupun penanganan terhadap korban Kekerasan terhadap Anak belum dapat dilakukan secara efektif, karena banyak masyarakat yang belum memahami tentang bagaimana batasan sesungguhnya yang dimaksud dengan Kekerasan terhadap Anak tersebut. Hal ini berkaitan dengan bentuk kekerasan, pelaku, maupun prevalensinya.Selain itu, juga bagaimanarespon yang seharusnya dapat dilakukan dalam menghadapi kejadian Kekerasan terhadap Anak (Fiqi, 2014; Regnaut et al., 2015). 
Analisis dilakukan berdasarkan fakta-fakta di lapangan berdasarkan Survei Kekerasan terhadap Anak (SKTA) tahun 2013. Survei ini dilakukan oleh Kementerian Sosial dan Kementerian Pemberdayaan Perempuan dan Perlindungan Anak dengan dukungan BAPPENAS (Badan Perencanaan Pembangunan Nasional), Badan Pusat Statistik (BPS), dan Centers for Desease Control and Prevention, Amerika Serikat. Analisis ini dilakukan berdasarkan pada fakta-fakta riil yang terjadi di masyarakat, dengan tujuan agar masyarakat mengetahui bahwa Kekerasan terhadap Anak bukanlah suatu peristiwa yang memang layak terjadi di masyarakat. Ini menyebabkan sebagian masyarakat dapat tersadar dan tergugah untuk bersamasama melakukan pencegahan terhadap kejadian kekerasan yang mungkin dapat terjadi pada anak, dimanapun dan kapanpun (Armalis, 2008; Breen et al., 2015;Suharto, 2015).

Kekerasan terhadap Anak sudah menjadi isu global di dunia.Karakteristik dan bentuk Kekerasan terhadap Anak secara global mungkin berbeda-beda. Bentuk Kekerasan terhadap Anak yang terjadi di suatu negara mungkin akan berbeda dengan kekerasan anak di Indonesia. Dengan menjadikan Kekerasan terhadap Anak menjadi isu global, hal ini menunjukkan bahwa Kekerasan terhadap Anak telah menjadi masalah yang serius dan harus menjadi perhatian semua pihak.Kekerasan terhadap Anak seharusnya tidak hanya menjadi perhatian dari profesi pekerjaan sosial saja, tetapi juga harus menjadi perhatian dari seluruh stakeholders lain yang mempunyai keterkaitan dengan kesejahteraan anak. Minimnya dukungan dari para stakeholdersini akan menyebabkan peniadaan Kekerasan terhadap Anak menjadi mustahil. Kekerasan yang terjadi pada anak lakilaki maupun anak perempuankhususnya yang terjadi di dalam ranah rumah tangga cukup bervariasi di berbagai negara, misalnya:perlakuan yang salah (abuse) baik secara 
fisik maupun psikis, yang menjadikan anak mempunyai pengalaman yang buruk dan akhirnya akan mengalami trauma dengan bentuk yang bervariasi (Gubernur Jawa Tengah, 2013; Afifi et al., 2013).

Penelitian Emma Fulu (2014) dalam Suharto (2015) menunjukan bahwa persentase Kekerasan terhadap Anak yang tertinggi terjadi di negara Papua Nugini (PNG), dimana terdapat $67 \%$ laki-laki dan $49 \%$ perempuan, disusul kejadian kekerasan yang terjadi di Indonesia (Jayapura), dimana terdapat 50\% laki-laki, di Kamboja terdapat kekerasan terhadap 50\% perempuan dan 45\% laki-laki. Di Srilanka terjadi kekerasan terhadap 38\% laki-laki dan $21 \%$ perempuan, di Indonesia (di daerah urban) terdapat kekerasan terhadap 33\% laki-laki, di China terdapat kekerasan terhadap $26 \%$ laki-laki dan $12 \%$ perempuan, di Bangladesh (di daerah urban) terdapat kekerasan terhadap 19\% laki-laki, di Indonesia (di daerah pedalaman terdapat kekerasan terhadap 18\% laki-laki, dan di Bangladesh (di daerah pedalaman terdapat kekerasan terhadap13\% lakilaki(Suharto, 2015).

Berdasarkan kenyataan tersebut, maka dapat disimpulkan bahwa di beberapa negara, sebagian besar korban kekerasan adalah laki-laki dibandingkan dengan perempuan.Padahal sebagian masyarakat menganggap bahwa perempuan lebih rentan menjadi korban kekerasan daripada laki-laki.Faktor ketatnya kontrol atau penjagaan terhadap anak perempuan merupakan pemicu rentannya anak laki-laki untuk menjadi korban kekerasan. Karena kontrol keluarga akanlebih terfokus kepada anak perempuan, maka anak laki-laki justru kurang mendapatkan pengawasan, sehingga kekerasan lebih mungkin terjadi pada anak laki-laki.

Upaya pencegahan KtA dapat melibatkan aktivasi organisasi-organisasi kemasyarakatan yang ada misalnya: 
PKK dan organisasi keagamaan. Pengadaan dan penambahan tenaga sosial profesional baik secara kuantitas ataupun kualitas di mana mereka akan berpartisipasi aktif dalam melakukanpencegahan, pengurangan risiko dan pendampingan baik pada korban ataupun pelaku Kekerasan terhadap Anak. Selain itu tenaga sosial ini akan sangat berperan dalam proses penyiapan keluarga dan lingkungan saat proses reintegrasi dan reunifikasi ketika terjadi kasus kekerasan dilingkungan.Diharapkan tersedia program home care dengan penganggaran dari provinsi, sehingga anak tetap dapat tinggal bersama keluarga dan bersekolah.

Peningkatankapasitastokohmasyarakat,tokohagama, perangkat desa, guru, Lembaga Sosial Masyarakat (LSM) untuk mampu berperan serta dalam upaya pencegahan Kekerasan terhadap Anak.Peningkatan kapasitas keluarga TKI terkait perlindungan anak khususnya dalam pola asuh dan kewajiban orangtua ketika meninggalkan keluarga. Revitalisasi program Bina Keluarga TKI agar keluarga TKI bisa mengatur dana dan aset yang diperoleh dari penghasilan mereka diluar negeri. Selain itu memberikan peningkatan ketrampilan dan life skill pada keluarga TKI. Ekstensifikasi kualitas program dan layanan pada program Bina Keluarga TKI dimana anggotanya adalah keluarga TKI dan TKI yang sudah pulang, sehingga apabila TKI sudah pulang diharapkan mereka mampu berkarya didalam negeri sehinggamerekatidak harus kembali lagi ke luar negeri untuk kepentingan terbaik bagi anak.

Aktivasi dan replikasi JPA (Jaringan Perlindungan Anak) di tingkat desa seperti yang ada di Desa Taman Gede Kecamatan Gemuh dengan penerbitan SK Bupati sehingga mampu menjadi mobilisator terkait upaya perlindungan anak di tingkat akar rumput dan di masyarakat.Pengadaan shelter khususnya bagi korban anak yang mengalami 
kekerasan.Menerbitkan aturan pemerintah kabupaten yang lebih selektif dalam perekrutan pekerja ke luar negeri baik dari sisi kompetensi kerja dan legalitasnya. Pemantauan dan sosialisasi secara terus menerus terkait program peningkatan kapasitas keluarga dan perlindungan anak khusunya pada kantong-kantong TKI di Kabupaten Kendal.Pelibatan sekolah-sekolah secara aktif dalam upaya-upaya pencegahan Kekerasan terhadap Anak secara holistik integratif.

Dan Disnakertrans dapat menyediakan data yang lebih akurat dan valid terkait dengan jumlah TKI dan calon TKI serta negara tujuan TKI yang dilengkapi dengan sistem monitoring kondisi TKI dinegara tujuan secara reguler sebagai upaya perlindungan tenaga kerja dan menyusun program pendampingan pada keluarga tenaga kerja luar negeri. Serta dibuat forum-forum CSR (Corporate Social Responsibility)khususnya terkait program CSR peduli perlindungan anak yang dapat memberikan kontribusi kepada anak-anak yang orang tuanya berprofesi sebagai TKI.

\section{Simpulan}

Berdasarkan proses wawancara dan FGD yang dilakukan oleh peneliti dengan para stakeholder yang terkait TKI dan anak, maka dapat disimpulkan bahwa faktor yang paling dominan yang berhubungan dengan kejadian Kekerasan terhadap Anak (KtA) dengan orang tua berprofesi TKI, yaitu: faktor pendapatan dan jenis pekerjaan.Pada faktor pendapatan, orangtua yang berprofesi sebagai TKI rata-rata memiliki pendapatan yang cukup tinggi, namun tidak diimbangi dengan pengetahuan dan kemampuan mengelola keuangan yang baik untuk anak dan keluarganya. Faktor jenis pekerjaan profesi TKI menuntut orang tua harus bekerja diluar rumah baik ayah 
ataupun ibu dengan jarak yang relatif jauh dan waktu yang relatif lama, sehingga anak-anak mereka dirumah tanpa pengasuhan adekuat secara langsung dari orang tua mereka sendiri. Pola asuh anak yang diberikan oleh orang tua pengganti sangat kurang mencukupi, sehingga membuat anak rentan menjadi korban atau pelaku kekerasan. Sementara disisi lain, secara pribadi anak belum mampu menghadapi dengan bijak berbagai pengaruh negatif dari pergaulan dilingkungannya,dan pengaruh negatif yang dapat ditimbulkan dari kemudahan dalam mengakses semua konten dalam Teknologi Informasi (TI), misalnya: internet dan media sosial.

Upaya pencegahan KtA dapat melibatkan sinergitas berbagai unsur peran serta unsur pemerintah, swasta dan masyarakat drai hulu hingga hilir. Keterlibatan organisasi sosial kemasayrakatan, tenaga sosial, peningkatan kapasitas tokoh masyarakat, tokoh agama, guru, keterlibatan perusahaaan melalui forum-forum CSR (Corporate Social Responsibility) dan ketegasan pemerintah dari tingkat desa hingga pusat. Sinergitas ini merangkum berbagai kegiatan sosialisasi, pendampingan, penerbitan regulasi hingga penyediaan sarana prasarana peduli anak dan shelter bagi anak korban KtA. 


\section{DAFTAR PUSTAKA}

Afifi, T.O., Mota, N., MacMillan, H.L., 2013, “Harsh Physical Punishment in Childhood and Adult Physical Health" Pediatrics Vol. 132(2), pp.333-42.

Ahmed, A., Wan-yuen, C., Marret, M.J., 2015, “Child Maltreatment Experience among Primary School Children: A Large Scale Survey in Selangor State, Malaysia" PLoS One. 2015(1), pp.1-15.

Armalis., 2008, “Hubungan Kekerasan Fisik dan Kekerasan Emosional Terhadap Kesehatan Jiwa Anak Usia Sekolah diSekolah Dasar Negeri 09 Berok Kecamatan Padang Barat Kota Padang" Skripsi, Padang: Fakultas Keperawatan Universitas Andalas.

Aulina, C.N., 2013, "Penanaman Disiplin pada Anak Usia Dini" Pedagogia Vol. 2(1), pp. 36-49.

Breen, A., Daniels, K., Tomlinson, M., 2015. “Children's Experiences of Corporal Punishment: A Qualitative Study in an Urban Township of South Africa", Child Abuse and Neglec Vol .48, pp.131-9.

Cheng,H.U.I.G., Huang, Y., Anthony, J.C., 2011, “'Childhood Physical Punishment and Later Alcohol Drinking Consequences: Evidence From a Chinese Context" dalam Journal of Studies on Alcohol and Drugs Vol. 72, pp.24-33.

Fataruba, R., Purwatiningsih, S.W.Y., 2009"Hubungan Pola Asuh dengan Kejadian Kekerasan" Jurnal Kesehatan Mayarakat Vol. 3(3), pp.168- 73.

Fiqi, N., 2014, “Hubungan Kekerasan Emosional dan Kekerasan Fisik Orang Tua dengan Konsep Diri pada Remaja di SMP N 35 Padang" Skripsi, Universitas Andalas.

Flaherty, E.G., Sege, R.D., Griffith, J., 2008,"From Suspicion of Physical Child Abuse to Reporting: Primary Care Clinician Decision-Making' dalam Pediatrics Vol. 122 
(3), pp.611-21.

Gubernur Jawa Tengah, 2013, Peraturan Daerah Provinsi Jawa

Tengah Nomor 7 tahun 2013 tentang Penyelenggaraan Perlindungan Anak. Semarang: Pemerintah Daerah Jawa Tengah.

Kemeterian Sosoial RI, 2013, Survey Terhadap Kekerasan Anak (SKTA) tahun 2013,

Hartanto, Y. D., 2009, “Hubungan Perilaku Kekerasan pada Anak dalam Keluarga dengan Prestasi Belajar Anak Kelas III-VI SD" dalam Keperawatan,

Hidayat, T., Ery, P.E.R., 2014, “Pengalaman Ibu Tentang Kekerasan Pada Anak di Kelurahan Kalibeber Kecamatan Mojotengah Kabupaten Wonosobo Tahun 2012" Jurnal Ilmu Kesehatan Keperawatan.10(2), pp.78-90.

Hyoscyamina, D.E., 2011. “Peran Keluarga dalam Membangun Karakter Anak" dalam Jurnal Psikologi Undip Vol 10 (2), pp.144-52.

Ikawati, A., 2013, “Jurnal Kekerasan Ibu Single Parent Terhadap Anak" dalam http://psikologi.ub.ac.id/ wpcontent/uploads/2013/10/Jurnal-KekerasanIbuSingle parent-Terhadap-Anak-by-AgustinIkawati.pdf.

Komisi Perlindungan Anak Indonesia, 2018, Penelitian KPAI tahun 2017 di Indonesia tentang Kekerasan terhadap Anak.

Mackowlez, J., 2013, "Verbal Abuse in Upbringing as The Cause of Low Self-esteem in Children" dalam Euoropean Scientific Journal, Vol 2.

Munawati, 2011, “Hubungan Verbal Abuse dengan Perkembangan Kognitif pada Anak Usia Prasekolah di RW 04 Kelurahan Rangkapan Jaya Baru Depok" Skripsi Universitas Pembangunan Nasional Veteran Jakarta. 
Nindya, P.N., Margaretha, R., 2012, “Hubungan Antara Kekerasan Emosional Pada Anak Terhadap Kecenderungan Kenakalan Remaja" dalam Jurnal Psikologi Klinik dan Kesehatan Mental.1(2), pp.1-9.

Noh, C.H.C \& Talaat, W.I.A.W., 2012, Verbal Abuse on Children: Does It Amount to Child Abuse under the Malaysian Law dalam Asian Social Science, Vol 8 (6).

Peni, T., 2013, “Kekerasan Pada Anak (Child Abuse) di Pendidikan Anak Usia Dini Mojokerto" Hospital Majapahit Vol. 5(2), pp.1-18.

Praditama, S., Nurhadi, Budiarti, A.C., 2015, “Kekerasan terhadap Anak Dalam Keluarga Dalam Perspektif Fakta Sosial' dalam Sosialitas; Jurnal Ilmiah Penidikan. Sosiologi Antropologi, Vol. 5(2),pp. 1-18.

Putri, Annora Mentari., Santoso, Agus., 2012, “Persepsi Orang Tua tentang Kekerasan Verbal pada Anak" dalam Jurnal Nursing Studies, 1(1), pp. 22-29.

Regnaut, O., Steenhouwer, M.J., \& Manaouil, C., 2015, “ Risk Factors for Child Abuse: Levels of Knowledge and Difficulties in Family Medicine. A Mixed Method Study" dalam Biomedicine Central Vol. 8(1), pp.1-6.

Suharto, Edi., 2015, “Kekerasan terhadap Anak Respon Pekerja Sosial" dalam Kawistara Vol 5 (1), pp. 47 - 56.

Suharsono, J.T., 2009, “Hubungan Pola Asuh Orang Tua Terhadap Kemampuan Sosialisasi Pada Anak Prasekolah di TK Pertiwi Purwokerto Utara" dalam Jurnal Keperawatan Vol. 4, pp.112- 118.

Syarniah, \& Lestari, M., 2014, “ Hubungan Pola Asuh Orang Tua Dengan Harga Diri Pada Remaja di SMP Negeri 12 Banjarmasin Tahun 2014" dalam Jurnal Citra Keperawatan Vol. 2 (1).

Unicef, 2014, Studi tentang Kekerasan terhadap Anak di Kabupaten Klaten dan Kabupaten Pemalang Jawa Tengah tahun 2013. 